\title{
Ring transformation of chromone-3-carboxylic acid under nucleophilic conditions
}

\author{
Magdy A. Ibrahim \\ Department of Chemistry, Faculty of Education, Ain Shams University, Roxy 11711, \\ Cairo, Egypt \\ E-mail: magdy_ahmed1977@yahoo.com
}

\begin{abstract}
The effect of sodium hydroxide solution on chromone-3-carboxylic acid (1) afforded $\omega$-formyl2-hydroxyacetophenone (2) and 1-(3-chromonyl)-2-(2-hydroxybenzoyl)ethene (3). The reactivity of carboxylic acid $\mathbf{1}$ towards primary and secondary amines, hydrazines, cyanoacetohydrazide, cyanoacetamide and malononitrile in different media led to interestingly ring transformation via $\gamma$-pyrone and carboxylic group. Structures of the products have been established on the basis of elemental analysis and spectral data.
\end{abstract}

Keywords: Chromone-3-carboxylic acid, enaminones, chroman-2,4-diones, ring transformation, chromenopyrazole, nitrogen and carbon nucleophiles

\section{Introduction}

Derivatives of 4-oxo-4H-chromenes represent useful synthetic building blocks in organic and medicinal chemistry. ${ }^{1-4}$ The introduction of an electron-withdrawing group at 3-position of chromone system changes crucially the reactivity of the pyrone ring with respect to nucleophiles, and provides a broad synthetic potential of 3-substituted chromones. ${ }^{5-7}$ The diversity of properties of these compounds is due to the highly reactive push-pull alkene system with a good leaving group at the $\beta$-carbon atom, whose role is played by the phenolate anion. Also, 3substituted chromones have the ability to undergo additional transformation related to $\gamma$-pyrone ring opening at C-2 position and ring closure (RORC) at C-4 position or at the substituent at C-3 position. $^{8-9}$ The chemistry of nucleophilic reactions involving RORC of chromone-3-carboxylic acid (1) attracted our attention due to rare literature reports. Also, in these very few reports we face some encountering results. ${ }^{10-12}$ The product obtained from the reaction of carboxylic acid 1 with phenylhydrazine had been established to be 4-oxo-1-phenyl-chromeno[4,3-c]pyrazole, ${ }^{10}$ not the corresponding isomer 2-phenyl-chromeno[4,3-c]pyrazol-3 $(2 H)$-one as previously reported by Ghosh. ${ }^{11}$ Also, reaction of 1 with hydroxylamine hydrochloride was reported to give 5-oxo-4,5dihydro-1,4-benzoxazepine-3-carboxylic acid. ${ }^{11}$ However, Chantegrel found the same reaction gave 5-(2-hydroxyphenyl)isoazole. ${ }^{12}$ Finally, reaction of 1 with guanidine carbonate gave 2- 
aminochromeno[4,3-d]pyrimidin-4(4H)-one. ${ }^{10}$ Herein, the behavior of chromone-3-carboxylic acid (1) towards sodium hydroxide and some nitrogen and carbon nucleophiles was studied in different reaction conditions.

\section{Results and Discussion}

The effect of one molar aqueous sodium hydroxide solution on 2-methylchromone-3-carboxylic acid was studied previously by Klutchko ${ }^{9}$ where no reaction or rearrangement took place at $20{ }^{\circ} \mathrm{C}$ but on warming degradation of chromone ring was observed and salicylic acid was obtained. Herein, chromone-3-carboxylic acid (1) in the presence of sodium hydroxide solution undergoes different reactions depending on the concentration of sodium hydroxide and reaction conditions. Thus, treatment of 1 with $0.025 \mathrm{M}$ sodium hydroxide solution in refluxing ethanol afforded $\omega$ formyl-2-hydroxyacetophenone (2), while when the reaction carried out using $0.05 \mathrm{M}$ aqueous sodium hydroxide solution at $70{ }^{\circ} \mathrm{C}$, 1-(3-chromonyl)-2-(2-hydroxybenzoyl)ethene (3) was obtained (Scheme 1). Compounds $\mathbf{2}$ and $\mathbf{3}$ were found to be identical with an authentic samples prepared according to Schönberg ${ }^{14}$ and Prakash, ${ }^{15}$ respectively. This rearrangement was explained through opening of the pyrone ring by sodium hydroxide solution followed by decarboxylation producing $\omega$-formyl-2-hydroxyacetophenone (2) which underwent self condensation $^{16}$ in aqueous sodium hydroxide solution to produce the dimeric product 3 (Scheme 1). Both compounds $\mathbf{2}$ and $\mathbf{3}$ gave red color with ferric chloride solution. The IR spectra showed characteristic absorption bands at $3421(\mathrm{OH})$ and $3449(\mathrm{OH}) \mathrm{cm}^{-1}$ for compounds 2 and $\mathbf{3}$, respectively. ${ }^{1} \mathrm{H}$ NMR spectrum of compound 3 displayed characteristic signals at 9.05 (H-2 of chromone ring) and $12.35\left(\mathrm{OH}\right.$ proton exchangeable with $\left.\mathrm{D}_{2} \mathrm{O}\right) \mathrm{ppm}$. Also, for the olefinic protons only the down field doublet is visible; $\beta$ to the carbonyl group, while the signal of the other one is overlapped by the complex multiplet of the signals of the 1,2-disubstituted rings in the range 6.99-8.20 ppm. The mass spectrum of compound 3 exhibited the molecular ion peak at $\mathrm{m} / \mathrm{z} 292(22 \%)$ and its base peak at $\mathrm{m} / \mathrm{z} 171$.

Treatment of chromone-3-carboxylic acid (1) with benzaldehyde in ethanolic sodium hydroxide solution $(0.025 \mathrm{M})$ afforded 3-( $\alpha$-hydroxybenzyl)chromone (4). This reaction proceeds through the formation of $\omega$-formyl-2-hydroxyacetophenone (2) which undergoes an aldol condensation and cyclization through addition of hydroxyl group to the aldehyde function followed by dehydration (Scheme 1). ${ }^{17}$ The IR spectrum of compound 4 showed characteristic absorption bands for $\mathrm{OH}$ and $\mathrm{C}=\mathrm{O}$ groups at 3423 and $1633 \mathrm{~cm}^{-1}$, respectively. Its ${ }^{1} \mathrm{H}$ NMR spectrum displayed characteristic signals at 3.90, 4.79 and $8.43 \mathrm{ppm}$ assigned to $\mathrm{PhCH}, \mathrm{OH}$ and $\mathrm{H}-2$ protons, respectively.

It is well known that the pyrone ring in chromone ${ }^{18}$ can be easily opened under the influence of primary and secondary amines with the formation of enaminones with a 2-hydroxyphenyl substituent at the carbonyl group. Surprisingly, the same products were obtained when chromone-3-carboxylic acid (1) was allowed to react with primary and secondary amines in 
ethanol, where the enaminones $\mathbf{5 a - h}$ were obtained (Scheme 2). The melting points of these products are sharply identical with those obtained previously by Krzysztof. ${ }^{18}$ The electron

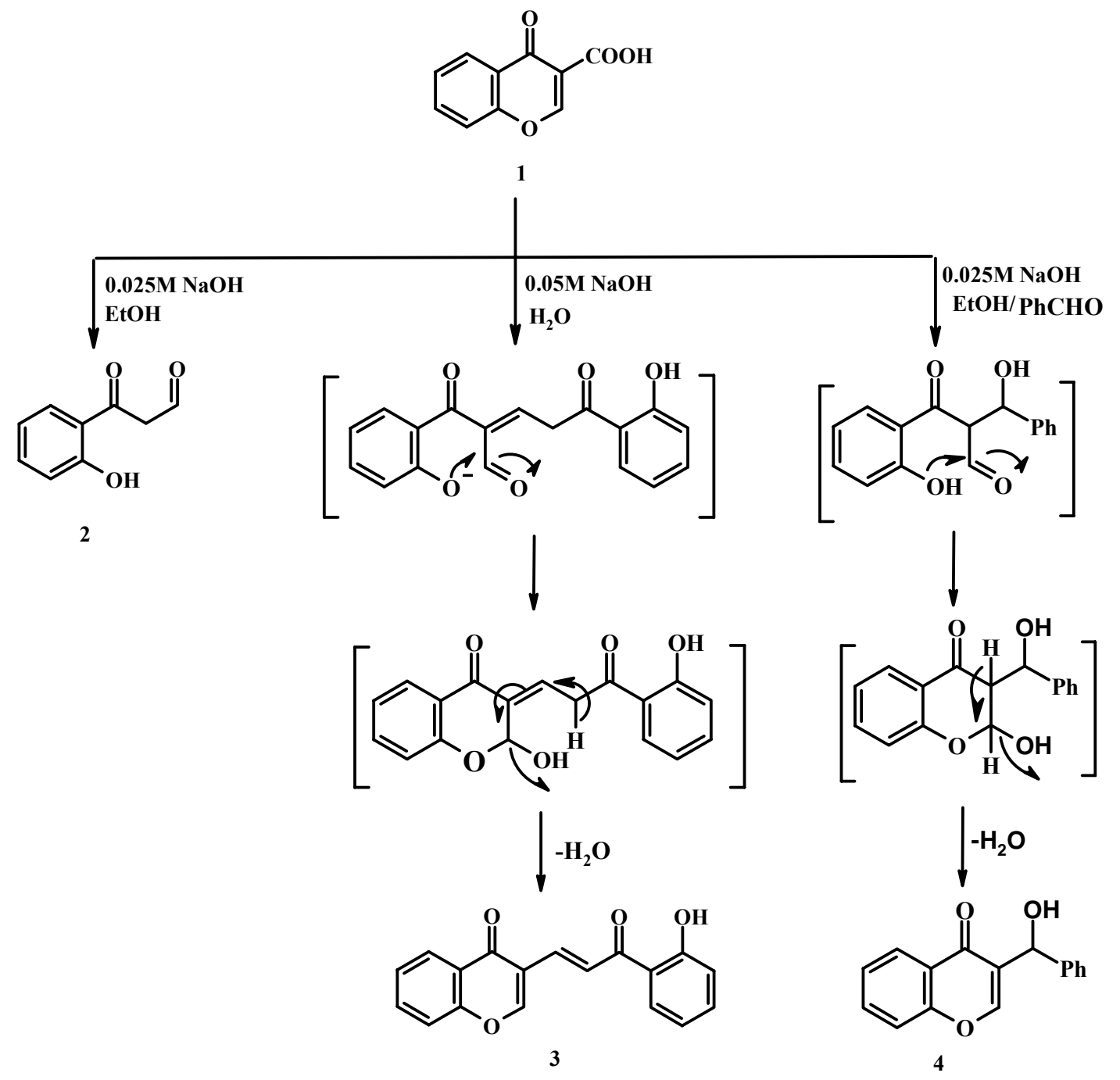

Scheme 1. Synthetic pathway for the preparation of compounds 2-4.

withdrawing carboxylic group in 2-unsubstituted-chromone-3-carboxylic acid (1) enhances the electrophilicity of C-2 atom of the pyrone ring. Thus, the suggested route for the formation of enaminones 5a-h involves nucleophilic attack of primary or secondary amino group at C-2 of compound 1 with concomitant opening of the pyrone ring followed by decarboxylation (Scheme 2). Structures of compounds $\mathbf{5 a - h}$ were also confirmed by cyclization with $50 \% \mathrm{HCl}$, where unsubstituted chromone (6) was obtained with mp $59^{\circ} \mathrm{C}\left(\right.$ lit. $\left.^{14} 59^{\circ} \mathrm{C}\right)$. No reactions took place when tertiary amines were allowed to react with compound 1. According to these results, chromone-3-carboxylic acid (1) can be used for identification of primary and secondary amines as $\omega$-formyl-2-hydroxyacetophenone and unsubstituted chromone. ${ }^{18}$ On the other hand, when 
carboxylic acid $\mathbf{1}$ was allowed to react with primary amines such as aniline and $n$-propylamine in glacial acetic acid, 3-(phenyl/n-propyl)aminomethylenechroman-2,4-dione (7a,b) were isolated as stereoisomeric ( $Z$ and $E$ ) mixtures (Scheme 2). The $Z: E$ ratio of compound $7 \mathbf{a}$ was found to be $3: 4$, respectively. The $Z: E$ ratio was determined from studies of the ${ }^{1} \mathrm{H}$ NMR spectrum. The relatively higher deshielding effect on the $\beta-\mathrm{H}$ which is cis to the cyclic ester (lactone) function of an $\alpha, \beta$-unsaturated ester compared to that of an $\alpha, \beta$-unsaturated ketone helps to distinguish the $Z$ and $E$ isomers. The ${ }^{1} \mathrm{H}$ NMR spectrum of compound $7 \mathrm{a}$ revealed the presence of two doublets at 13.47 and $11.83 \mathrm{ppm}$ assigned to $\mathrm{NH}$ protons in both $Z$ and $E$ isomers, respectively. The high $\delta$ values are attributed to the intramolecular hydrogen bond in both isomers. Also, the spectrum exhibited two doublets at 8.92 and $8.89 \mathrm{ppm}$ for the exocyclic $=\mathrm{CH}$ protons in $E$ and $\mathrm{Z}$ isomers, respectively. The two doublets at 13.47 and $11.85 \mathrm{ppm}$ were disappeared by shaking with $\mathrm{D}_{2} \mathrm{O}$ with concomitant collapsing of the two doublets at 8.92 and $8.89 \mathrm{ppm}$ to singlets. The melting point of compound $7 \mathbf{a}$ was found to be identical with the earlier reported. ${ }^{19,20}$ In a similar manner, compound $\mathbf{7 b}$ exists in a stereoisomeric $(Z$ and $E$ ) mixture in 2:3 ratio, respectively, (c.f. experimental). The reaction may be proceeds through ring opening followed by ring closure (RORC) between the phenolic hydroxyl and carboxylic acid functions without decarboxylation (Scheme 2). The above results confirm the loss of $\mathrm{CO}_{2}$ molecule after opening of pyrone ring in ethanol but no decarboxylation occurred in acetic acid medium.

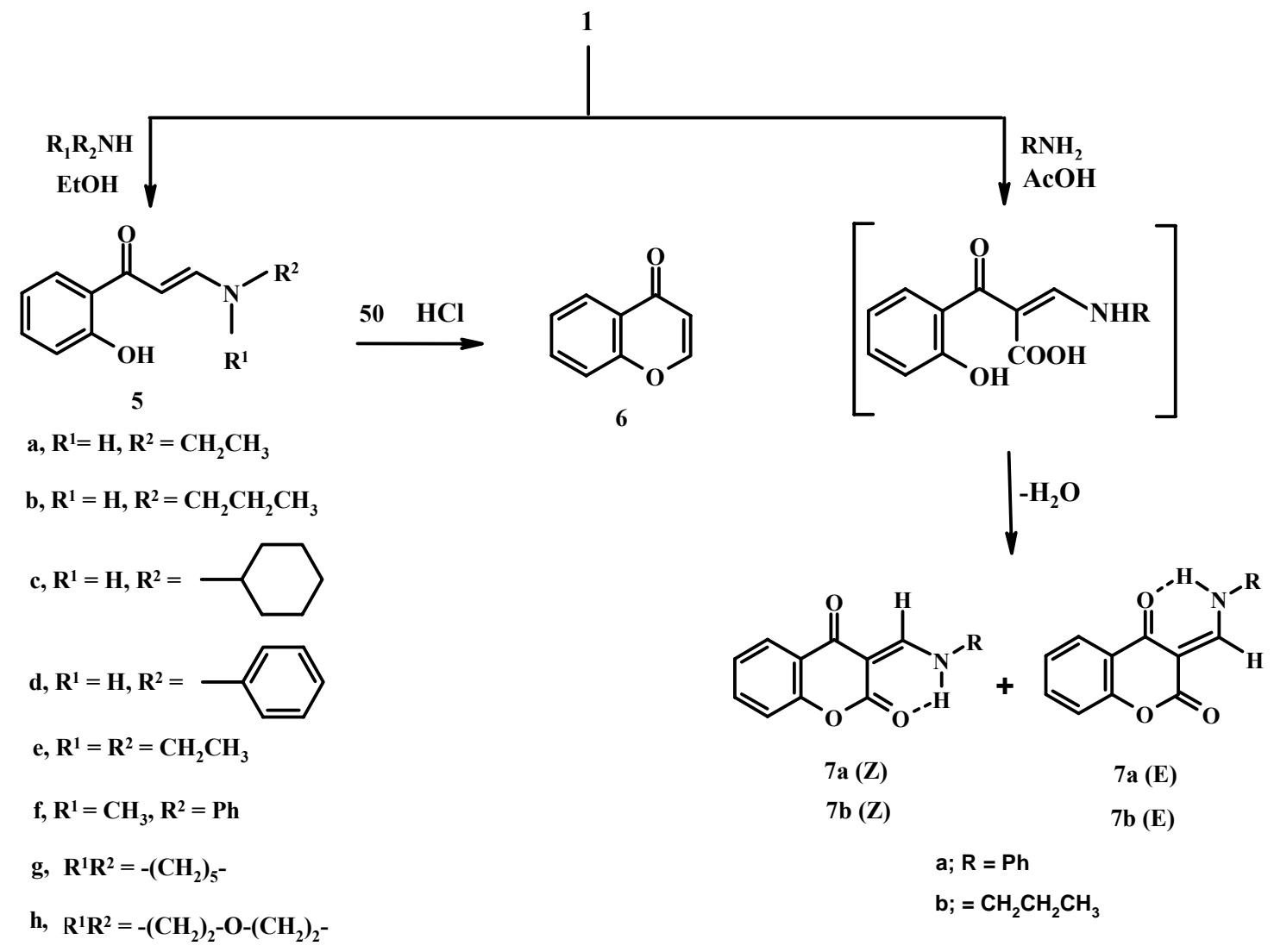

Scheme 2. Reaction of carboxylic acid $\mathbf{1}$ with a variety of amines in different media. 
3-[N'-(7-chloroquinolin-4-yl)hydrazino]-1-(2-hydroxyphenyl)-prop-2-en-1-one (9) and 1-(7chloroquinolin-4-yl)chromeno[4,3-c]pyrazol-4(1H)-one (10) were obtained from the reaction of carboxylic acid 1 with 7-chloro-4-hydrazinoquinoline (8) in ethanol and acetic acid, respectively. Cyclization of compound 9 in dimethylformamide afforded the pyrazole derivative 11 (Scheme 3). Compound 9 was found to be a stereoisomeric mixture of $Z$ and $E$ isomers in 2:3 ratio, respectively, as indicated from ${ }^{1} \mathrm{H}$ NMR studies of the spectrum.

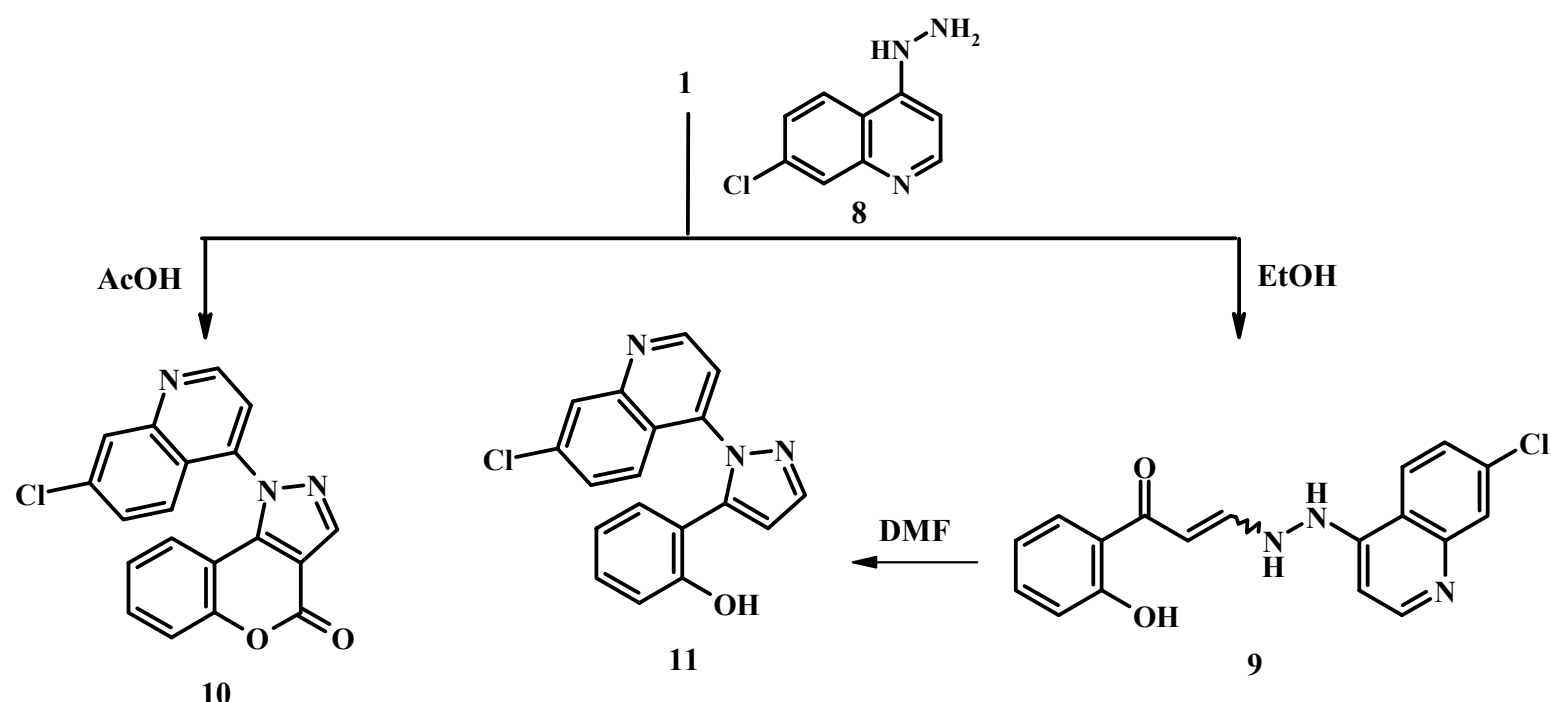

Scheme 3. Reaction of carboxylic acid 1 with 7-chloro-4-hydrazinoquinoline (8).

Reaction of chromone-3-carboxylic acid (1) with cyanoacetohydrazide was studied in different media. Therefore, reaction of $\mathbf{1}$ with cyanoacetohydrazide in ethanol and acetic acid gave compounds 12 and $\mathbf{1 3}$, respectively. When the later reaction takes place in sodium ethoxide compound 14 was isolated, while the $\mathrm{N}$-amino pyridine derivative 15 was not obtained (Scheme 4). Compounds 12-14 are produced in the course of the ring transformation because cyanoacetohydrazide thereby acts as an ambient nucleophile, that is, as both $\mathrm{N}$ - and $\mathrm{C}$ nucleophile. ${ }^{21}{ }^{1} \mathrm{H}$ NMR measurements showed a stereoisomeric $(Z$ and $E$ ) mixture in 2:3 ratio, respectively, of 2-cyano- $N$ '-[3-(2-hydroxyphenyl)-3-oxoprop-1-en-1-yl)]acetohydrazide (12). Its IR spectrum showed absorption bands at 3275,3201 and $2262 \mathrm{~cm}^{-1}$ for $\mathrm{OH}, \mathrm{NH}$ and $\mathrm{C} \equiv \mathrm{N}$ groups, respectively. The ${ }^{1} \mathrm{H}$ NMR studies of chromeno[4,3-c]pyrazol-4(1H)-one (13) showed singlet signal at $9.12 \mathrm{ppm}(\mathrm{H}-3)$ and a broad signal exchangeable with $\mathrm{D}_{2} \mathrm{O}$ at $13.23 \mathrm{ppm}(\mathrm{NH}$ proton), while its IR spectrum showed characteristic absorption bands at 3217 and $1735 \mathrm{~cm}^{-1}$ for $\mathrm{NH}$ and $(\mathrm{OC}=\mathrm{O})$ groups, respectively. The $\mathrm{C} \equiv \mathrm{N}$ group was disappeared in the spectrum due to loss of one molecule of cyanoacetic acid as seen in Scheme $4 .{ }^{21}$ The ${ }^{1} \mathrm{H}$ NMR spectrum of 7hydroxy-3-(2-hydroxyphenyl)-1H-1,2-diazepine-6-carbonitrile (14) revealed three different broad signals exchangeable with $\mathrm{D}_{2} \mathrm{O}$ at $12.35,12.95$ and $13.34 \mathrm{ppm}$ corresponding to one $\mathrm{NH}$ and two $\mathrm{OH}$ protons, while its IR spectrum showed a broad absorption band at $3243 \mathrm{~cm}^{-1}$ for NH 
and $\mathrm{OH}$ groups. Refluxing compound 12 in dimethylformamide afforded the well known 3-(2hydroxyphenyl)-1H-pyrazole (16). ${ }^{22}$ Compounds 13 and 16 were obtained authentically from the reaction of carboxylic acid $\mathbf{1}$ with hydrazine hydrate in acetic acid and ethanol, respectively (Scheme 4).

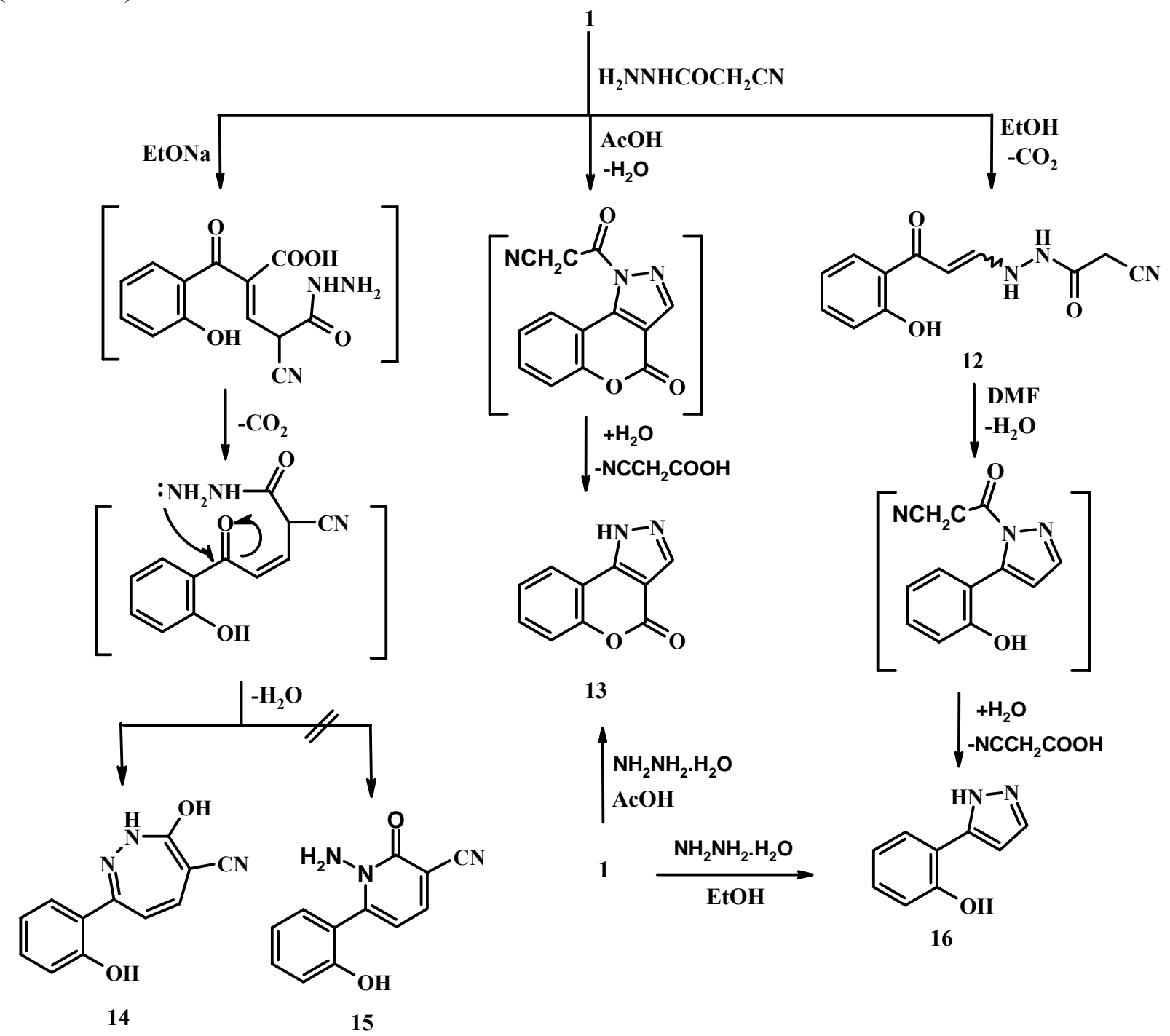

Scheme 4. Reaction of carboxylic acid 1 with cyanoacetohydrazide in different media.

Reaction of chromone-3-carboxylic acid (1) with some carbon nucleophiles was studied. Therefore, treatment of 1 with cyanoacetamide in ethanol containing few drops of triethylamine as catalyst afforded 6-(2-hydroxyphenyl)-2-oxo-1,2-dihydropyridine-3-carbonitrile (17) (Scheme 5). The IR spectrum of compound 17 showed absorption bands at 3375 and $3172 \mathrm{~cm}^{-1}$ assigned to $\mathrm{OH}$ and $\mathrm{NH}$ groups, respectively. Its ${ }^{1} \mathrm{H}$ NMR spectrum revealed a broad signal exchangeable with $\mathrm{D}_{2} \mathrm{O}$ at $11.94 \mathrm{ppm}$ for the $\mathrm{NH}$ and $\mathrm{OH}$ protons. On the other hand, reaction of 1 with malononitrile in ethanol containing few drops of triethylamine as catalyst afforded (4E)-2- 
amino-3-cyanobenzo[b]oxocin-6-one (18). The latter compound was obtained authentically from condensation reaction of compound 2 with malononitrile under the same conditions (Scheme 5). The other possible product 19 was excluded on the basis of the spectral data. Compound 18 gave no color with ferric chloride solution. The IR spectrum of compound $\mathbf{1 8}$ showed the presence of characteristic bands attributed to the amino group at $3443,3326,3212 \mathrm{~cm}^{-1}$. Its ${ }^{1} \mathrm{H}$ NMR spectrum exhibited broad signal exchangeable with $\mathrm{D}_{2} \mathrm{O}$ at $8.75 \mathrm{ppm}$ assigned to $\mathrm{NH}_{2}$ protons, in addition to two doublets at 6.52 and $9.02 \mathrm{ppm}$ with the same coupling constant $(J=12.8 \mathrm{~Hz})$. The latter two signals are attributed to the two hydrogen atoms in the benzoxocin-2-one 18, that are trans as illustrated from their coupling constant $(J=12.8 \mathrm{~Hz})$. The higher down field shift of the $\delta$ value of the $\mathrm{H}_{\beta}$ to $\mathrm{C}=\mathrm{O}$ (H-4 proton) attributed to the higher deshielding of this proton. Triethylamine was used as a catalyst for deprotonation of cyanoacetamide and malononitrile, while piperidine should be avoided because it reacts more rapidly as secondary amine with compound $\mathbf{1}$ producing compound $\mathbf{5 g}$.

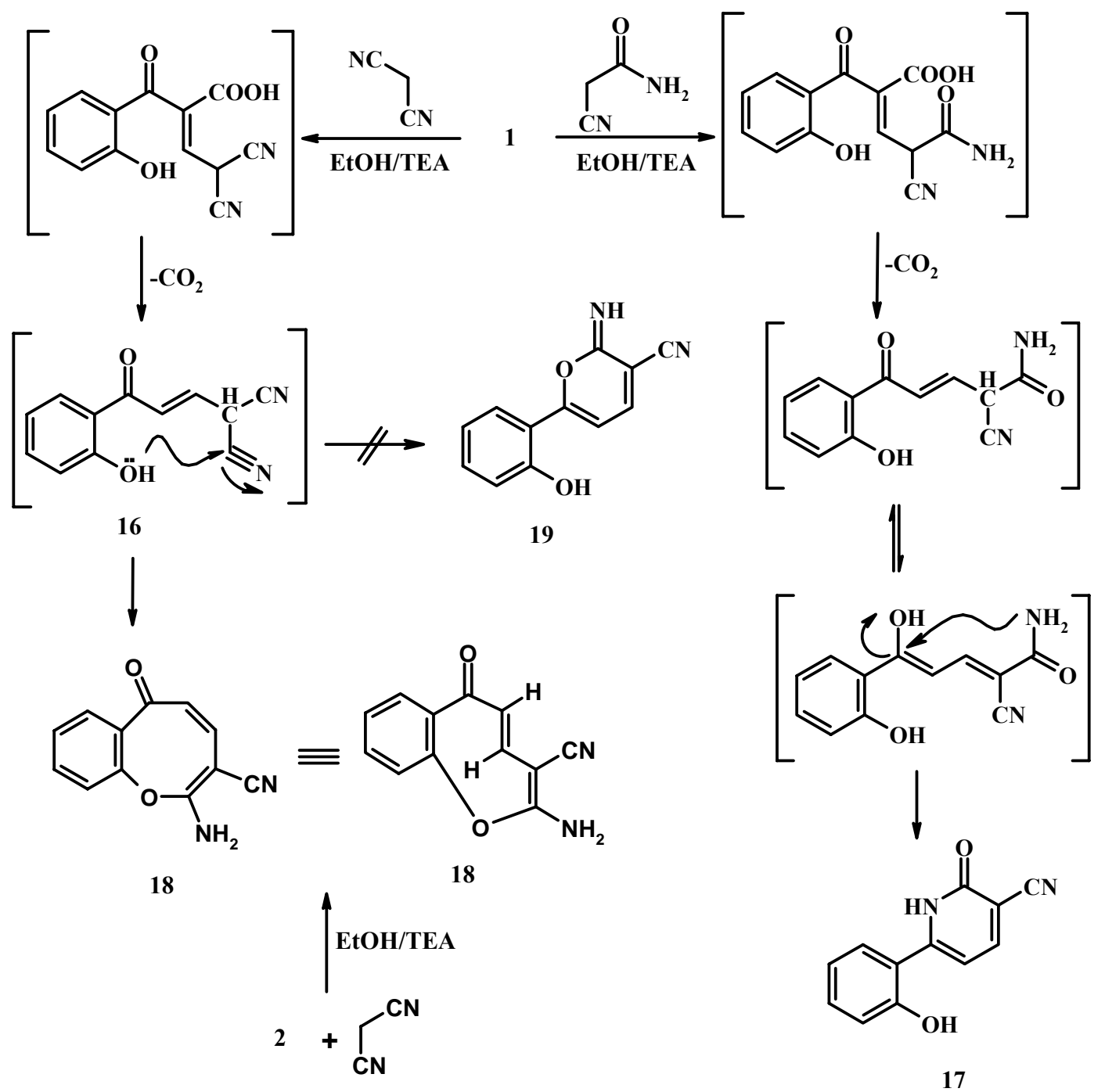

Scheme 5. Reaction of carboxylic acid $\mathbf{1}$ with cyanoacetamide and malononitrile. 


\section{Conclusions}

This work reports the chemical reactivity of chromone-3-carboxylic acid towards sodium hydroxide solution and a variety of nitrogen and carbon nucleophiles. The products obtained when the reaction took place in ethanol are similar to those obtained from $\omega$-formyl-2hydroxyacetophenone, indicating loss of carbon dioxide during the course of reaction.

\section{Experimental Section}

General Procedures. All melting points are uncorrected and were recorded in open capillary tubes on a Stuart SMP3 melting point apparatus. Infrared spectra were recorded on FT-IR Bruker Vector 22 spectrophotometer using $\mathrm{KBr}$ wafer technique. ${ }^{1} \mathrm{H}$ NMR spectra were measured on Gemini spectrometer $200 \mathrm{MHz}$ using DMSO- $d_{6}$ as solvent and TMS (chemical shift in $\delta$ ) as an internal standard. Mass spectra were obtained using gas chromatography GCMS qp 1000 ex Shimadzu instrument mass spectrometer $(70 \mathrm{eV})$. Elemental microanalyses were performed at the Cairo University Microanalytical Center. Chromone-3-carboxylic acid (1) was prepared according to the reported method. ${ }^{23}$

(-Formyl-2-hydroxyacetophenone (2). A mixture of $1(0.19 \mathrm{~g}, 1 \mathrm{mmol})$ and $0.025 \mathrm{M}$ sodium hydroxide solution $(2 \mathrm{~mL})$ in ethanol $(5 \mathrm{~mL})$ was refluxed on water bath for $1 \mathrm{~h}$. After cooling the reaction mixture was diluted by water $(5 \mathrm{~mL})$ and neutralized with $5 \%$ acetic acid. The solid obtained was filtered and crystallized from benzene/petroleum ether (40-60) to give $\mathbf{2}$ as colorless crystals, mp $104-105{ }^{\circ} \mathrm{C}$ (lit. $\left.{ }^{14} 105{ }^{\circ} \mathrm{C}\right)$, yield $(0.06 \mathrm{~g}, 37 \%)$. IR $\left(\mathrm{KBr}, \mathrm{cm}^{-1}\right): 3421$ $(\mathrm{OH}), 3063\left(\mathrm{CH}_{\text {arom. }}\right), 2922\left(\mathrm{CH}_{2}\right), 1692\left(\mathrm{C}=\mathrm{O}_{\text {aldehyde }}\right), 1651(\mathrm{C}=\mathrm{O})$ and $1611(\mathrm{C}=\mathrm{C})$.

1-(3-Chromonyl)-2-(2-hydroxybenzoyl)ethene (3). A mixture of $\mathbf{1}(0.19 \mathrm{~g}, 1 \mathrm{mmol})$ and $0.05 \mathrm{M}$ sodium hydroxide solution $(5 \mathrm{~mL})$ was heated at $70^{\circ} \mathrm{C}$ for $1 \mathrm{~h}$. After cooling the reaction mixture was diluted by water $(5 \mathrm{~mL})$ and neutralized with $5 \%$ acetic acid. The solid obtained was filtered, washed several times with water and crystallized from dioxane $/ \mathrm{H}_{2} \mathrm{O}$ to give $\mathbf{3}$ as yellow crystals, mp $173{ }^{\circ} \mathrm{C}$ (lit. $\left.{ }^{15} 173-174{ }^{\circ} \mathrm{C}\right)$, yield $\left(0.14 \mathrm{~g}, 48 \%\right.$ ). IR $\left(\mathrm{KBr}, \mathrm{cm}^{-1}\right)$ : $3449(\mathrm{OH}), 3046\left(\mathrm{CH}_{\text {arom. }}\right)$, $1653\left(\mathrm{C}=\mathrm{O}_{\text {pyrone }}\right), 1615(\mathrm{C}=\mathrm{O})$ and $1573(\mathrm{C}=\mathrm{C}) .{ }^{1} \mathrm{H}$ NMR (DMSO, $)$ ): 6.99-8.20 (m, 9H, Ar-H of disubstituted rings and one olefinic proton; $\alpha$ to the carbonyl group), 8.35 (d, $1 \mathrm{H}, J=15.5 \mathrm{~Hz}$, $=\mathrm{CH}$ trans $), 9.05(\mathrm{~s}, 1 \mathrm{H}, \mathrm{H}-2$ of chromone ring $)$ and $12.35 \mathrm{ppm}(\mathrm{s}, 1 \mathrm{H}, \mathrm{OH}$ exchangeable with $\left.\mathrm{D}_{2} \mathrm{O}\right) . \mathrm{M} / \mathrm{e}$ (Int. \%): $\mathrm{M}+1 \quad(293 ; 5), \mathrm{M}^{+}(292 ; 22), 171\left(\mathrm{M}^{+}-\mathrm{COC}_{6} \mathrm{H}_{4} \mathrm{OH} ; 100\right)$ and 121 $\left({ }^{+} \mathrm{COC}_{6} \mathrm{H}_{4} \mathrm{OH}\right.$; 13). Anal. Calcd for $\mathrm{C}_{18} \mathrm{H}_{12} \mathrm{O}_{4}$ (292.29): C, 73.97; H, 4.14. Found: C, 73.86; H, 4.12

3-( $\alpha$-Hydroxybenzyl)chromone (4). A mixture of $1(0.19 \mathrm{~g}, 1 \mathrm{mmol})$ and benzaldehyde $(0.1$ $\mathrm{mL}, 1 \mathrm{mmol})$, in $0.025 \mathrm{M}$ sodium hydroxide solution $(5 \mathrm{~mL})$ and ethanol $(5 \mathrm{~mL})$, was refluxed on water bath for $2 \mathrm{~h}$. After cooling the reaction mixture was diluted by water $(5 \mathrm{~mL})$ and neutralized with $5 \%$ acetic acid. The solid obtained was filtered and crystallized from ethanol to 
give 4 as white crystals, mp $119-120{ }^{\circ} \mathrm{C}$ (lit. $\left.{ }^{17} 120{ }^{\circ} \mathrm{C}\right)$, yield $(0.07 \mathrm{~g}, 28 \%)$. IR $\left(\mathrm{KBr}, \mathrm{cm}^{-1}\right)$ : $3423(\mathrm{OH}), 3073\left(\mathrm{CH}_{\text {arom. }}\right), 1633(\mathrm{C}=\mathrm{O})$ and $1573(\mathrm{C}=\mathrm{C}) .{ }^{1} \mathrm{H}$ NMR (DMSO, $\left.\delta\right): 3.90$ (d, $1 \mathrm{H}, \mathrm{CH}-$ O), 4.79 (bs, 1H, OH), 6.96 (m, 2H, Ar-H), 7.51-8.04 ppm (m, 6H, Ar-H), 8.19 (d, 1H, H-5), 8.43 (s, 1H, H-2). Anal. Calcd for $\mathrm{C}_{16} \mathrm{H}_{12} \mathrm{O}_{3}$ (252.27): C, 76.18; H, 4.79. Found: C, 76.25; H; 4.70 .

1-(2-Hydroxyphenyl)-3-(substituted) prop-2-en-1-one (5a-h). A mixture of 1 (0.19 g, 1 mmol) and primary or secondary amines namely; ethylamine, $n$-propylamine, cyclohexylamine, aniline, diethylamine, $N$-methylaniline, piperidine and morphiline $(1 \mathrm{mmol})$ in ethanol $(5 \mathrm{~mL})$ was refluxed on water bath for $15 \mathrm{~min}$. The solid obtained after cooling was filtered and crystallized to give 5a-h, respectively. 5a; crystallized from ethanol as yellow crystals, mp $86-87{ }^{\circ} \mathrm{C}$ (lit. ${ }^{18}$ $\left.86-87{ }^{\circ} \mathrm{C}\right)$, yield $(0.15 \mathrm{~g}, 79 \%)$. 5b; crystallized from methanol as yellow crystals, mp $63-64{ }^{\circ} \mathrm{C}$ (lit. $\left.{ }^{18} 63-64{ }^{\circ} \mathrm{C}\right)$, yield $(0.1 \mathrm{~g}, 49 \%)$. 5c; crystallized from ethanol as pale yellow crystals, $\mathrm{mp}$ $115-116{ }^{\circ} \mathrm{C}$ (lit. $\left.{ }^{18} 115-116{ }^{\circ} \mathrm{C}\right)$, yield $(0.16 \mathrm{~g}, 66 \%)$. 5d; crystallized from ethanol as cumene crystals, mp $144-145^{\circ} \mathrm{C}$ (lit. $\left.{ }^{18} 144-145^{\circ} \mathrm{C}\right)$, yield $(0.17 \mathrm{~g}, 71 \%)$. 5e; crystallized from ethanol as yellow crystals, mp $77-78^{\circ} \mathrm{C}$ (lit. $\left.{ }^{18} 77-78{ }^{\circ} \mathrm{C}\right)$, yield $(0.15 \mathrm{~g}, 68 \%)$. 5f; crystallized from ethanol as yellow crystals, mp $95-96{ }^{\circ} \mathrm{C}$ (lit. $\left.{ }^{18} 95-96{ }^{\circ} \mathrm{C}\right)$, yield $(0.16 \mathrm{~g}, 63 \%)$. 5g; crystallized from methanol as yellow crystals, mp $118-119^{\circ} \mathrm{C}$ (lit. $\left.{ }^{18} 118-119{ }^{\circ} \mathrm{C}\right)$, yield $(0.18 \mathrm{~g}, 78 \%$ ). 5h; crystallized from ethanol as yellow crystals, mp $110-111^{\circ} \mathrm{C}$ (lit. $\left.{ }^{18} 110-111{ }^{\circ} \mathrm{C}\right)$, yield $(0.14 \mathrm{~g}, 60$ $\%)$.

4-Oxo-4H-Chromene (6). A mixture of $\mathbf{5 a - h}(1 \mathrm{mmol})$ and $50 \% \mathrm{HCl}(10 \mathrm{~mL})$ was refluxed on water bath for $2 \mathrm{~h}$. After cooling, the solution was diluted with water and allowed to stand. The solid obtained was filtered off and recrystallized from petroleum ether (40/60) to give 6 as colorless crystals, mp $59{ }^{\circ} \mathrm{C}$ (lit. ${ }^{14} 59{ }^{\circ} \mathrm{C}$ ).

3-(Phenyl/n-propyl)aminomethylenechroman-2,4-dione (7a,b). A mixture of 1 (0.19 g, 1 mmol) and aniline or $n$-propylamine $(1 \mathrm{mmol})$ in acetic acid $(5 \mathrm{~mL})$ was refluxed for $1 \mathrm{~h}$. After cooling the reaction mixture was diluted with water. The solid obtained was filtered and crystallized to give 7a,b. Compound 7a crystallized from ethanol as white crystals, mp 204-205 ${ }^{\circ} \mathrm{C}$ (lit. $\left.{ }^{19,20} 204-205{ }^{\circ} \mathrm{C}\right)$, yield $(0.08 \mathrm{~g}, 30 \%)$. IR $\left(\mathrm{KBr}, \mathrm{cm}^{-1}\right): 3185(\mathrm{NH}), 3046\left(\mathrm{CH}_{\text {arom. }}\right), 1720$ ( $\mathrm{OC}=\mathrm{O}$ for $E$ isomer), $1689\left(\mathrm{OC}=\mathrm{O}\right.$ for $\mathrm{Z}$ isomer), $1652(\mathrm{C}=\mathrm{O})$ and $1604(\mathrm{C}=\mathrm{C}) .{ }^{1} \mathrm{H}$ NMR (DMSO, $\delta): 7.33-8.26(\mathrm{~m}, 9 \mathrm{H}, \mathrm{Ar}-\mathrm{H}), 8.89(\mathrm{~d}, 1 \mathrm{H}$, exocyclic $=\mathrm{CH}, J=15.4 \mathrm{~Hz}, \mathrm{Z}$ isomer, exchanged to singlet with $\left.\mathrm{D}_{2} \mathrm{O}\right), 8.92(\mathrm{~d}, 1 \mathrm{H}$, exocyclic $=\mathrm{CH}, J=14 \mathrm{~Hz}, E$ isomer, exchanged to singlet with $\left.\mathrm{D}_{2} \mathrm{O}\right), 11.85\left(\mathrm{~d}, 1 \mathrm{H}, \mathrm{NH}\right.$, exchangeable with $\mathrm{D}_{2} \mathrm{O}, E$ isomer $)$ and $13.47 \mathrm{ppm}(\mathrm{d}, 1 \mathrm{H}$, $\mathrm{NH}$, exchangeable with $\mathrm{D}_{2} \mathrm{O}, Z$ isomer). Compound $\mathbf{7 b}$ crystallized from methanol as white crystals, mp $>300^{\circ} \mathrm{C}$, yield $(0.10 \mathrm{~g}, 43 \%)$. IR $\left(\mathrm{KBr}, \mathrm{cm}^{-1}\right): 3246(\mathrm{NH}), 3055\left(\mathrm{CH}_{\text {arom }}\right), 1718$ ( $\mathrm{OC}=\mathrm{O}$ for $E$ isomer), $1686\left(\mathrm{OC}=\mathrm{O}\right.$ for $\mathrm{Z}$ isomer), $1643(\mathrm{C}=\mathrm{O})$ and $1615(\mathrm{C}=\mathrm{C}) .{ }^{1} \mathrm{H}$ NMR (DMSO, $\delta): 0.95\left(\mathrm{t}, 3 \mathrm{H}, \mathrm{CH}_{3}\right), 1.33\left(\mathrm{~m}, 2 \mathrm{H}, \mathrm{CH}_{2}\right), 2.82\left(\mathrm{t}, 2 \mathrm{H}, \mathrm{CH}_{2}\right), 7.51(\mathrm{~d}, 1 \mathrm{H}, \mathrm{H}-8), 7.79(\mathrm{t}$, $1 \mathrm{H}, \mathrm{H}-6), 7.92(\mathrm{t}, 1 \mathrm{H}, \mathrm{H}-7), 8.21(\mathrm{~d}, 1 \mathrm{H}, \mathrm{H}-5), 8.72(\mathrm{~d}, 1 \mathrm{H}$, exocyclic $=\mathrm{CH}, J=14.6 \mathrm{~Hz}, \mathrm{Z}$ isomer, exchanged to singlet with $\left.\mathrm{D}_{2} \mathrm{O}\right), 8.81(\mathrm{~d}, 1 \mathrm{H}$, exocyclic $=\mathrm{CH}, J=14 \mathrm{~Hz}, E$ isomer, exchanged to singlet with $\left.\mathrm{D}_{2} \mathrm{O}\right), 10.48\left(\mathrm{~d}, 1 \mathrm{H}, \mathrm{NH}\right.$, exchangeable with $\mathrm{D}_{2} \mathrm{O}, E$ isomer $)$ and 11.65 
ppm (d, $1 \mathrm{H}, \mathrm{NH}$, exchangeable with $\mathrm{D}_{2} \mathrm{O}, \mathrm{Z}$ isomer). Anal. Calcd for $\mathrm{C}_{13} \mathrm{H}_{13} \mathrm{NO}_{3}$ (231.25): $\mathrm{C}$, 67.52; H, 5.67; N, 6.06. Found: C, 67.26; H; 5.42; N, 6.01.

3-[N`-(7-Chloroquinolin-4-yl)hydrazino]-1-(2-hydroxyphenyl)-prop-2-en-1-one (9).

A mixture of 1 (0.19 g, $1 \mathrm{mmol})$ and 7-chloro-4-hydrazinoquinoline (8) (0.194 g, $1 \mathrm{mmol})$ in ethanol $(10 \mathrm{~mL})$ was refluxed on water bath for $1 \mathrm{~h}$. The solid obtained after cooling was filtered and crystallized from ethanol to give 9 as yellow crystals, mp $218-219{ }^{\circ} \mathrm{C}$, yield $(0.15 \mathrm{~g}, 44 \%)$. IR (KBr, cm $\left.{ }^{-1}\right): 3305(\mathrm{OH}), 3213(2 \mathrm{NH}), 3063\left(\mathrm{CH}_{\text {arom. }}\right), 1634\left(\mathrm{C}=\mathrm{O}_{\text {enaminone }}\right)$ and $1612(\mathrm{C}=\mathrm{C})$. ${ }^{1} \mathrm{H}$ NMR (DMSO, $\left.\delta\right): 6.07\left(\mathrm{~d}, 1 \mathrm{H}\right.$, olefinic hydrogen, $\mathrm{H}_{\alpha}$ of $\left.\mathrm{C}=\mathrm{O}\right), 6.65(\mathrm{~d}, 1 \mathrm{H}$, olefinic hydrogen, $\mathrm{H}_{\beta}$ of $\left.\mathrm{C}=\mathrm{O}\right), 6.83(\mathrm{~d}, 2 \mathrm{H}, \mathrm{Ar}-\mathrm{H}), 7.09(\mathrm{~d}, 2 \mathrm{H}, \mathrm{Ar}-\mathrm{H}), 7.54(\mathrm{~s}, 1 \mathrm{H}, \mathrm{H}-8$ of quinoline ring), $7.84(\mathrm{t}, 2 \mathrm{H}, \mathrm{Ar}-\mathrm{H}, J=7.8 \mathrm{~Hz}), 8.11(\mathrm{~d}, 1 \mathrm{H}, \mathrm{H}-3$ of quinoline ring, $J=8.6 \mathrm{~Hz}), 8.34(\mathrm{~d}, 1 \mathrm{H}$, $\mathrm{H}-2$ of quinoline ring, $J=8.6 \mathrm{~Hz}$ ), 10.66 (bs, $1 \mathrm{H}, \mathrm{NH}$ exchangeable with $\mathrm{D}_{2} \mathrm{O}, E$ isomer), 11.05 (bs, $1 \mathrm{H}, \mathrm{NH}$ exchangeable with $\mathrm{D}_{2} \mathrm{O}, E$ isomer), 13.16 (bs, $1 \mathrm{H}, \mathrm{NH}$ exchangeable wit $\mathrm{D}_{2} \mathrm{O}, Z$ isomer), 13.59 (bs, $1 \mathrm{H}, \mathrm{NH}$ exchangeable with $\mathrm{D}_{2} \mathrm{O}, \mathrm{Z}$ isomer) and $14.70 \mathrm{ppm}(\mathrm{bs}, 1 \mathrm{H}, \mathrm{OH}$ exchangeable with $\mathrm{D}_{2} \mathrm{O}$ ). Anal. Calcd for $\mathrm{C}_{18} \mathrm{H}_{14} \mathrm{ClN}_{3} \mathrm{O}_{2}$ (339.78): C, 63.63; H, 4.15; N, 12.37 . Found: C, 63.22; H, 4.46; N, 12.04 .

1-(7-Chloroquinolin-4-yl)-chromeno[4,3-c]pyrazol-4(1H)-one (10). A mixture of 1 (0.19 g, 1 $\mathrm{mmol})$ and 7-chloro-4-hydrazinoquinoline (8) $(0.194 \mathrm{~g}, 1 \mathrm{mmol})$ in acetic acid (5 $\mathrm{mL})$ was refluxed for $1 \mathrm{~h}$. The solid obtained after cooling was filtered off and crystallized from acetic acid to give 10 as pale yellow crystals, mp $180-181{ }^{\circ} \mathrm{C}$, yield $(0.11 \mathrm{~g}, 32 \%)$. IR $\left(\mathrm{KBr}, \mathrm{cm}^{-1}\right)$ : $3073\left(\mathrm{CH}_{\text {arom. }}\right), 1704(\mathrm{OC}=\mathrm{O}) 1628(\mathrm{C}=\mathrm{N})$ and $1590(\mathrm{C}=\mathrm{C}) .{ }^{1} \mathrm{H}$ NMR (DMSO, $)$ ): 6.97-7.05 (d, 2H, Ar-H), 7.51 (t, 1H, H-8, J = 7.2 Hz), 7.75-7.89 (m, 2H, Ar-H), 8.24-8.35 (m, 2H, Ar-H), $8.41\left(\mathrm{~s}, 1 \mathrm{H}, \mathrm{H}-8^{\prime}\right), 9.05(\mathrm{~s}, 1 \mathrm{H}, \mathrm{H}-3)$ and $9.09 \mathrm{ppm}\left(\mathrm{d}, 1 \mathrm{H}, \mathrm{H}-2^{\prime}\right)$. Anal. Calcd for $\mathrm{C}_{19} \mathrm{H}_{10} \mathrm{ClN}_{3} \mathrm{O}_{2}$ (347.76): C, 65.62; H, 2.90; N, 12.08. Found: C, 65.58; H, 3.03; N, 12.16.

2-(7-Chloroquinolin-4-yl)-3-(2-hydroxyphenyl)pyrazole (11). Compound 9 (0.34 g, $1 \mathrm{mmol})$ in dimethylformamide $(10 \mathrm{~mL})$ was refluxed for $2 \mathrm{~h}$. The yellow crystals obtained after cooling was filtered and crystallized from $\mathrm{DMF} / \mathrm{H}_{2} \mathrm{O}$ to give 11 as yellow crystals, mp $251-252{ }^{\circ} \mathrm{C}$, yield (0.25 g, 78 \%). IR ( $\left.\mathrm{KBr}, \mathrm{cm}^{-1}\right): 3250(\mathrm{OH}), 3072\left(\mathrm{CH}_{\text {arom. }}\right), 1620(\mathrm{C}=\mathrm{N})$ and $1592(\mathrm{C}=\mathrm{C}) .{ }^{1} \mathrm{H}$ NMR (DMSO, $\delta$ ): 6.84-7.41 (m, 7H, Ar-H), 7.65 (d, 1H, H-5, J = 7.8 Hz), 8.14 (d, 1H, H-3 ' $J=$ $8.2 \mathrm{~Hz}$ ), 8.21 (s, 1H, H-8 '), 8.56 (d, 1H, H-2` $J=8.2 \mathrm{~Hz}$ ), 12.43 (bs, 1H, OH exchangeable with $\mathrm{D}_{2} \mathrm{O}$ ). Anal. Calcd for $\mathrm{C}_{18} \mathrm{H}_{12} \mathrm{ClN}_{3} \mathrm{O}$ (321.77): C, 67.19; H, 3.76; N, 13.06. Found: C, 66.79; H, $3.52 ; \mathrm{N}, 12.85$.

2-Cyano- $N$ `-[3-(2-hydroxyphenyl)-3-oxoprop-1-en-1-yl)] acetohydrazide (12). A mixture of 1 $(0.19 \mathrm{~g}, 1 \mathrm{mmol})$ and cyanoacetohydrazide $(0.10 \mathrm{~g}, 1 \mathrm{mmol})$ in ethanol $(10 \mathrm{~mL})$ was refluxed on water bath for $1 \mathrm{~h}$. The white crystals obtained after cooling was filtered and crystallized from ethanol to give 12 as white crystals, mp 236-237 ${ }^{\circ} \mathrm{C}$, yield $(0.12 \mathrm{~g}, 55 \%)$. IR $\left(\mathrm{KBr}, \mathrm{cm}^{-1}\right): 3275$ $(\mathrm{OH}), 3205(2 \mathrm{NH}), 3099\left(\mathrm{CH}_{\text {arom. }}\right), 2972,2931\left(\mathrm{CH}_{2}\right), 2262(\mathrm{C} \equiv \mathrm{N}), 1676\left(\mathrm{C}=\mathrm{O}_{\text {amide }}\right), 1618$ $\left(\mathrm{C}=\mathrm{O}_{\text {enaminone }}\right)$ and $1600(\mathrm{C}=\mathrm{C}) .{ }^{1} \mathrm{H}$ NMR $(\mathrm{DMSO}, \delta): 2.09\left(\mathrm{~s}, 2 \mathrm{H}, \mathrm{CH}_{2}\right), 5.5(\mathrm{~d}, 1 \mathrm{H}$, olefinic hydrogen, $\mathrm{H}_{\alpha}$ of $\left.\mathrm{C}=\mathrm{O}, J=14.6 \mathrm{~Hz}\right), 5.89\left(\mathrm{~d}, 1 \mathrm{H}\right.$, olefinic hydrogen, $\mathrm{H}_{\beta}$ of $\left.\mathrm{C}=\mathrm{O}, J=14.6 \mathrm{~Hz}\right)$, $6.95(\mathrm{t}, 2 \mathrm{H}, \mathrm{Ar}-\mathrm{H}), 7.35$ (d, 1H, Ar-H), 7.58 (d, 1H, Ar-H), 8.95 (bs, 1H, NH exchangeable with $\mathrm{D}_{2} \mathrm{O}, E$ isomer), 9.57 (bs, $1 \mathrm{H}, \mathrm{NH}$ exchangeable with $\mathrm{D}_{2} \mathrm{O}, E$ isomer), 9.95 (bs, $1 \mathrm{H}, \mathrm{OH}$ 
exchangeable with $\mathrm{D}_{2} \mathrm{O}, E$ isomer), 10.45 (bs, $1 \mathrm{H}, \mathrm{NH}$ exchangeable with $\mathrm{D}_{2} \mathrm{O}, \mathrm{Z}$ isomer), 10.89 (bs, $1 \mathrm{H}, \mathrm{NH}$ exchangeable with $\mathrm{D}_{2} \mathrm{O}, \mathrm{Z}$ isomer) and $13.49 \mathrm{ppm}(\mathrm{bs}, 1 \mathrm{H}, \mathrm{OH}$ exchangeable with $\mathrm{D}_{2} \mathrm{O}, \mathrm{Z}$ isomer). Anal. Calcd for $\mathrm{C}_{12} \mathrm{H}_{11} \mathrm{~N}_{3} \mathrm{O}_{3}$ (245.24): C, 58.77; H, 4.52; N, 17.13. Found: C, 58.69; H, 4.48; N, 16.94.

\section{Chromeno[4,3-c]pyrazol-4(1H)-one (13)}

Method A. A mixture of $1(0.19 \mathrm{~g}, 1 \mathrm{mmol})$ and cyanoacetohydrazide $(0.10 \mathrm{~g}, 1 \mathrm{mmol})$ in acetic acid ( $4 \mathrm{~mL})$ was refluxed for $2 \mathrm{~h}$. The solid obtained was filtered and crystallized from AcOH to give 13 as white crystals, mp 226-227 ${ }^{\circ} \mathrm{C}$, yield (0.09 g, $48 \%$ ).

Method B. A mixture of $1(0.38 \mathrm{~g}, 2 \mathrm{mmol})$ and hydrazine hydrate $(0.1 \mathrm{~mL}, 2 \mathrm{mmol})$ in acetic acid $(5 \mathrm{~mL})$ was refluxed for $2 \mathrm{~h}$. After cooling the reaction mixture was diluted with water. The solid obtained was filtered and crystallized from ethanol to give $\mathbf{1 3}$ as pale yellow crystals, $\mathrm{mp}$ 226-227 ${ }^{\circ} \mathrm{C}$, yield $(0.17 \mathrm{~g}, 46 \%)$. IR $\left(\mathrm{KBr}, \mathrm{cm}^{-1}\right): 3217(\mathrm{NH}), 3054\left(\mathrm{CH}_{\text {arom. }}\right), 1735(\mathrm{OC}=\mathrm{O})$ and $1603(\mathrm{C}=\mathrm{N}) .{ }^{1} \mathrm{H}$ NMR (DMSO, $\left.\delta\right) 7.61$ (t, 1H, H-8), 7.79 (d, 1H, H-6), 7.93 (t, 1H, H-7), 8.16 (d, 1H, H-9), 9.12 (s, 1H, H-3) and 13.23 ppm (bs, 1H, NH exchangeable with $\mathrm{D}_{2} \mathrm{O}$ ). Anal. Calcd for $\mathrm{C}_{10} \mathrm{H}_{6} \mathrm{~N}_{2} \mathrm{O}_{2}$ (186.17): C, 64.52; H, 3.25; N, 15.05. Found: C, 64.73; H, 3.22; N, 15.05 .

7-Hydroxy-3-(2-hydoxyphenyl)-1H-1,2-diazepine-6-carbonitrile (14). A mixture of 1 (0.19 g, $1 \mathrm{mmol})$ and cyanoacetohydrazide $(0.10 \mathrm{~g}, 1 \mathrm{mmol})$ in sodium ethoxide (4 $\mathrm{mL}$ prepared by dissolving of $0.023 \mathrm{~g}$ sodium in $4 \mathrm{~mL}$ absolute ethanol) was refluxed for $2 \mathrm{~h}$. After cooling the reaction mixture was neutralized with diluted $\mathrm{HCl}$. The solid obtained was filtered and crystallized from ethanol to give $\mathbf{1 4}$ as yellow crystals, $\mathrm{mp}>300{ }^{\circ} \mathrm{C}$, yield $(0.08 \mathrm{~g}, 32 \%)$. IR $\left(\mathrm{KBr}, \mathrm{cm}^{-1}\right)$ : 3243 (bs, NH and 2OH), $3065\left(\mathrm{CH}_{\text {arom. }}\right), 2266(\mathrm{C} \equiv \mathrm{N}), 1603(\mathrm{C}=\mathrm{N})$ and $1557(\mathrm{C}=\mathrm{C})$.

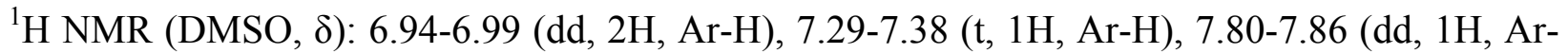
$\mathrm{H}), 8.05$ (d, 1H, Ar-H), 8.23-8.29 (dd, 1H, Ar-H), 12.35 (bs, 1H, NH exchangeable with $\mathrm{D}_{2} \mathrm{O}$ ), 12.95 (bs, $1 \mathrm{H}, \mathrm{OH}$ exchangeable with $\mathrm{D}_{2} \mathrm{O}$ ) and 13.34 (bs, $1 \mathrm{H}, \mathrm{OH}$ exchangeable with $\mathrm{D}_{2} \mathrm{O}$ ). Anal. Calcd for $\mathrm{C}_{12} \mathrm{H}_{9} \mathrm{~N}_{3} \mathrm{O}_{2}$ (227.22): C, 63.43; H, 3.99; N, 18.49. Found: C, 63.59; H, 3.82; N, 18.14 .

\section{3-(2-Hydroxyphenyl)pyrazole (16)}

Method A. Compound $12(0.25 \mathrm{~g}, 1 \mathrm{mmol})$ in DMF $(5 \mathrm{~mL})$ was refluxed for $1 \mathrm{~h}$. After cooling the reaction mixture was diluted with water. The solid obtained was filtered off and crystallized from benzene to give 16 as white crystals, mp $91-93^{\circ} \mathrm{C}$ (lit. ${ }^{22} 90-94{ }^{\circ} \mathrm{C}$, yield $(0.09 \mathrm{~g}, 56 \%)$.

Method B. A mixture of $1(0.38 \mathrm{~g}, 2 \mathrm{mmol})$ and hydrazine hydrate $(0.1 \mathrm{~mL}, 2 \mathrm{mmol})$ in ethanol $(10 \mathrm{~mL})$ was refluxed for $1 \mathrm{~h}$. After cooling the reaction mixture was diluted with water. The solid obtained was filtered and crystallized from benzene to give $\mathbf{1 6}$ as white crystals, mp $91-93{ }^{\circ} \mathrm{C}$, yield (0.14 g, $44 \%)$. IR (KBr, cm $\left.{ }^{-1}\right): 3403(\mathrm{OH}), 3285(\mathrm{NH}), 3061\left(\mathrm{CH}_{\text {arom. }}\right), 1609(\mathrm{C}=\mathrm{N})$ and $1595(\mathrm{C}=\mathrm{C})$.

6-(2-Hydroxyphenyl)-2-oxo-1,2-dihydropyridine-3-carbonitrile (17). A mixture of 1 (0.19 g, $1 \mathrm{mmol})$ and cyanoacetamide $(0.084 \mathrm{~g}, 1 \mathrm{mmol})$ in ethanol $(10 \mathrm{~mL})$ containing few drops of triethylamine was refluxed on water bath for $30 \mathrm{~min}$. The solid obtained after cooling was 
filtered and crystallized from $\mathrm{DMF} / \mathrm{H}_{2} \mathrm{O}$ to give $\mathbf{1 7}$ as pale yellow crystals, $\mathrm{mp}>300{ }^{\circ} \mathrm{C}$, yield (0.07 g, 33 \%). IR (KBr, cm $\left.{ }^{-1}\right): 3375(\mathrm{OH}), 3172(\mathrm{NH}), 3045\left(\mathrm{CH}_{\text {arom. }}\right), 2224(\mathrm{C} \equiv \mathrm{N}), 1652(\mathrm{C}=\mathrm{O})$ and $1603(\mathrm{C}=\mathrm{C}) .{ }^{1} \mathrm{H}$ NMR (DMSO, $\left.\delta\right) 6.72(\mathrm{~d}, 1 \mathrm{H}, \mathrm{Ar}-\mathrm{H}), 6.97-7.51(\mathrm{~m}, 4 \mathrm{H}, \mathrm{Ar}-\mathrm{H}), 8.17(\mathrm{~d}, 1 \mathrm{H}$, Ar-H) and 11.94 ppm (bs, $2 \mathrm{H}, \mathrm{NH}$ and $\mathrm{OH}$ exchangeable with $\mathrm{D}_{2} \mathrm{O}$ ). Anal. Calcd for $\mathrm{C}_{12} \mathrm{H}_{8} \mathrm{~N}_{2} \mathrm{O}_{2}$ (212.21): C, 67.92; H, 3.80; N, 13.20. Found: C, 67.78; H, 3.82; N, 13.17.

(4E)-2-Amino-3-cyanobenzo[b]oxocin-6-one (18). Method A. A mixture of 1 (0.38 g, $2 \mathrm{mmol})$ and malononitrile $(0.132 \mathrm{~g}, 2 \mathrm{mmol})$ in ethanol $(10 \mathrm{~mL})$ containing few drops of triethylamine was refluxed for $30 \mathrm{~min}$. The orange-red crystals obtained during heating was filtered and crystallized from DMF/EtOH to give 18 as orange-red crystals, mp 277-278 ${ }^{\circ} \mathrm{C}$, yield $(0.16 \mathrm{~g}, 38$ \%). Method B. A mixture of $2(0.164 \mathrm{~g}, 1 \mathrm{mmol})$ and malononitrile $(0.066 \mathrm{~g}, 1 \mathrm{mmol})$ in ethanol $(5 \mathrm{~mL})$ containing few drops of triethylamine was refluxed for $30 \mathrm{~min}$. The orange-red obtained during heating was filtered and crystallized from $\mathrm{DMF} / \mathrm{EtOH}$ to give $\mathbf{1 8}$ as orange-red crystals, mp $278{ }^{\circ} \mathrm{C}$, yield $(0.07 \mathrm{~g}, 33 \%)$. IR $\left(\mathrm{KBr}, \mathrm{cm}^{-1}\right): 3443,3326,3212\left(\mathrm{NH}_{2}\right), 2201(\mathrm{C} \equiv \mathrm{N}), 1652$ $(\mathrm{C}=\mathrm{O})$ and $1599(\mathrm{C}=\mathrm{C}) .{ }^{1} \mathrm{H}$ NMR (DMSO, $\left.\delta\right): 6.52(\mathrm{~d}, 1 \mathrm{H}, \mathrm{H}-5, J=12.8 \mathrm{~Hz}), 7.29-7.47$ (m, 2H, $\mathrm{H}-8$ and H-10), 7.60 (t, 1H, H-9, $J=8.2 \mathrm{~Hz}), 7.93(\mathrm{~d}, 1 \mathrm{H}, \mathrm{H}-7, J=7.8 \mathrm{~Hz}), 8.75$ (bs, 2H, NH exchangeable with $\left.\mathrm{D}_{2} \mathrm{O}\right)$ and $9.02 \mathrm{ppm}(\mathrm{d}, 1 \mathrm{H}, \mathrm{H}-4, J=12.8 \mathrm{~Hz})$. Anal. Calcd for $\mathrm{C}_{12} \mathrm{H}_{8} \mathrm{~N}_{2} \mathrm{O}_{2}$ (212.21): C, 67.92; H, 3.80; N, 13.20. Found: C, 67.75; H, 3.82; N, 13.11.

\section{References}

1. Sosnovskikh, V. Ya.; Irgashev, R. A.; Levchenko, A. A. Tetrahedron 2008, 64, 6607.

2. Farag, N. A.; Mohamed, S. R.; Soliman G. A. H. Bioorg. Med. Chem. 2008, 16, 9009.

3. Prakash, O.; Kumar, R.; Parkash, V. Eur. J. Med. Chem. 2008, 43, 435.

4. Liu, J.; Wu, J.; Zaho, Y. X.; Deng, Y. Y.; Mei, W. L.; Dai, H. F. Chin. Chem. Lett. 2008, 19, 934.

5. Sosnovskikh, V. Ya.; Moshkin, V. S.; Kodess, M. I. Tetrahedron Lett. 2008, 49, 6856.

6. Sosnovskikh, V. Ya.; Moshkin, V. S.; Irgashev, R. A. Tetrahedron Lett. 2006, 47, 8543.

7. Abdel-Rahman, A. H.; Hammouda, M. A. A.; El-Desoky, S. I. Heteroat. Chem. 2005, 16, 20.

8. Gašparová, R., Lácová, M. Molecules 2005, 10, 937.

9. Ghosh, C. K. J. Heterocycl. Chem. 1983, 20, 1437.

10. Chantegrel, B.; Nadi, A.; Gelin, S. Tetrahedron Lett. 1983, 24, 381.

11. Ghosh, C. K.; Mukhopadhyay, K. K. Synthesis 1978, 10, 779.

12. Chantegrel, B.; Nadi, A.; Gelin, S. J. Org. Chem. 1984, 49, 4419.

13. Klutchko, S.; Shavel, J.; Strandtmann, M. V. J. Org. Chem. 1974, 39, 2436.

14. Schönberg, A.; Sina, A. J. Am. Chem. Soc. 1950, 72, 3396.

15. Prakash, O.; Kumar, R.; Sharma D.; Bhardwaj V. J. Indian Chem. Soc. 2004, 81, 888.

16. Széll, T.; Sohár, P.; Horváth, G. Liebigs Ann. 1995, 2043.

17. Eiden, F.; Haverland, H. Chem. Ber. 1967, 100, 2554.

18. Krzysztof, K.; Chem. Anal. 1969, 14, 1145; Chem. Abstr. 1972, 72, 128468n. 
19. Bandyopadhyay, C.; Sur, K. R.; Patra, R.; Sen, A. Tetrahedron 2000, 56, 3583.

20. Ishar, M. P. S.; Kumar, K.; Singh R. Tetrahedron Lett. 1998, 39, 6547.

21. Weker, M.; Perpetuo, G.; Lugar P. J. Heterocycl. Chem. 1995, 32, 249.

22. http://www.sigmaaldrich.com/catalog/search/ProductDetail/ALDRICH/417831

23. Machida, Y.; Nomoto, S.; Negi, S.; Jkuta, H.; Saito, I. Synth. Commun. 1980, 10, 889. 